\title{
SCIENTIFIC SUBSTANTIATION OF IMPROVEMENT OF THE ECOLOGICAL-HYGIENIC MONITORING PROCEDURE OF POTABLE AND NATURAL WATERS QUUALITY

\author{
Zorina O.V.
} \\ НАУЧНОЕ ОБОСНОВАНИЕ СОВЕРШЕНСТВОВАНИЯ ПОРЯДКА ЭКОЛОГО- ГИГИЕНИЧЕСКОГО МОНИТОРИНГА КАЧЕСТВА ПРИРОДНЫХ И ПИТЬЕВЫХ ВОД
}

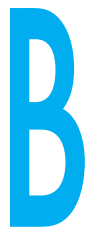

ЗОРИНА О.В.

ГУ "Институт общественного здоровья им. А.Н. Марзеева

HAMHY",

г. Киев, Украина

УДК 614.777:504.064.3

Ключевые слова:

мониторинг, природные

воды, питьевые воды, пункт

соответствия,

периодичность контроля.
Украине отсутствует адекватная система мониторинга качества природных и питьевых вод, что негативно отражается на экологической и эпидемической ситуации в стране [1-5]. Существующий порядок наблюдений в системе мониторинга осуществляется на определенных пунктах по специально разработанной каждым ведомством программе контроля водных ресурсов. Ведомственная разобщенность, дублирование функций приводят к нарушению основных принципов организации и проведения контроля качества водных ресурсов, которыми являются комплексность и систематичность наблюдений, согласованность сроков их проведения с характерными гидрологическими ситуациями, применение единых показателей качества воды и методов их определения.

Изменить сложившуюся ситуацию возможно внедрением нового порядка мониторига природных и питьевых вод согласно национальным документам, разработанным с целью имплементации Водной Рамочной Директивы 2000/60 /EC, Директивы 98/83/EC о
НАУКОВЕ ОБҐРУНТУВАННЯ УДОСКОНАЛЕННЯ ПОРЯДКУ ЕКОЛОГО-ГІГІЕНІЧНОГО МОНІТОРИНГУ ЯКОСТІ ПРИРОДНИХ І ПИТНИХ ВОД Зоріна О.В.

ДУ "Інститут громадського здоров'я ім. О.М. Марзєєва НАМНУ", м. Київ, Україна

Мета. Наукове обґрунтування та удосконалення параметрів і критеріїв моніторингу якості природних і питних вод з урахуванням вимог європейського законодавства.

Матеріали. Проведено аналіз європейської та української нормативної документації щодо контролю якості природних і питних вод. Досліджено якість водопровідних питних вод із поверхневих і підземних джерел питного водопостачання, із пунктів розливу і фасованих за санітарно-хімічними показниками у різних областях України протягом останніх 17 років (понад 600 проб).

Методи: бібліографічний, нормативно

пошуковий, санітарно-гігієнічні, санітарно-хімічні та експертної оцінки

Результати. У роботі науково обґрунтовано та удосконалено параметри і критерії моніторингу якості вод, враховуючи вимоги європейського законодавства та результати багаторічного вивчення пріоритетних показників якості природних $і$ питних вод, а також їхнього впливу на здоров'я споживачів. Зазначено, що розробка програми порядку моніторингу питних вод має проводитися з урахуванням результатів моніторингу природних вод. Удосконалено критерії аналізу моніторингу вод, запропоновано аналізувати наявність проблемних показників, концентрації яких перевищують гігієнічний норматив для питних вод до або/та після очищення, а також нестабільні і наближені до рівня зазначеного нормативу (більше 0,75 нормативу). Порівняльна оцінка Директиви 98/83/ЄС та ДСанПін 2.2.4-171-10 щодо порядку моніторингу якості питних вод за мікробіологічними та органолептичними показниками показала, що за продуктивності водопро- воду <13000 м³/добу ДСанПіН передбачено жорсткіший контроль, що доцільно зберегти у разі імплементації зазначеної Директиви. Виявлено відсутність порядку контролю якості питної води щодо вмісту залишкових кількостей реагентів та гігієнічні нормативи для них (регламентовано у ДСанПін 2.2.4-171-10), що мають залишитися й у поновленому національному нормативному документі. Встановлено, що доочищені водопровідні питні води із поверхневих та підземних джерел питного водопостачання мають стабільний склад, тому вимоги до якості таких вод та періодичність їх контролю мають бути однаковими. Для знесоленої питної води з штучною мінералізацією у пунктах розливу продуктивністю до $5 \mathrm{~m}^{3} /$ добу знижено частоту визначення мінеральних речовин (замість одного разу на тиждень передбачено один раз на місяць). Запропоновано для питних вод у разі знезараження діоксидом хлору встановити норматив для хлоратів згідно з рекомендаціями ВООЗ (0,7 мг/л) та проводити його контроль один раз на місяць; для питних вод, що потребують очищення від тригалогенметанів, слід встановити жорсткіший контроль якості питної води на вміст цих канцерогенних речовин (не рідше одного разу на три місяці). Вперше зазначено, що після переобладнання системи водопостачання та змін у технології водопідготовки виробники можуть проводити контроль якості питної води не за повним переліком показників, а лише за тими, які можуть змінюватися, що є економічно доцільним. Запропоновано впроваджувати комплексний еколого-гігієнічний моніторинг природних та питних вод за новим порядком, що буде суттєвим кроком до поліпшення якості питних вод та впровадження європейського законодавства в Україні.

Ключові слова: моніторинг, природні води, питні води, пункт відповідності, періодичність контролю. 
качестве воды, предназначенной для употребления человеком, и др.

Данная работа выполнялась в рамках проекта "Поддержка Украины в аппроксимации европейского законодательства" ("Support to Ukraine in approximation of the EU environmental acquis") "APENA projekt".

Цель. Научное обоснование и усовершенствование параметров и критериев мониторинга качества природных и питьевых вод с учетом требований европейского законодательства.

Материалы и методы. При проведении исследований использованы методы нормативно-поисковый, санитарно-

Таблица
Порядок проведения мониторинга качеста питьевой воды согласно Директиве 98/83/ЕС (с изменениями 2015 года)

\begin{tabular}{|c|c|c|c|}
\hline \multicolumn{2}{|c|}{$\begin{array}{c}\text { Объем питьевой воды, которая } \\
\text { производится или распределяется } \\
\text { в пределах зоны снабжения } \\
\text { (производительность), м³/сут. } \\
\text { (примечания } 1 \text { и 2) }\end{array}$} & \multirow{2}{*}{\begin{tabular}{|c} 
Показатели \\
группы A, \\
количество \\
проб в год \\
(примечание 3)
\end{tabular}} & \multirow{2}{*}{$\begin{array}{c}\text { Показатели } \\
\text { группы Б, } \\
\text { количество } \\
\text { проб в год } \\
\text { (примечание 3) } \\
>0\end{array}$} \\
\hline & 100 & & \\
\hline$>100$ & $\leq 1000$ & 4 & 1 \\
\hline$>1000$ & $\leq 10000$ & \multirow{3}{*}{$\begin{array}{c}4+3 \text { для } \\
\text { каждых } \\
1000 \text { м³}^{3} \text { сут. } \\
\text { и части из } \\
\text { общего } \\
\text { объема }\end{array}$} & $\begin{array}{c}1+1 \text { для каждых } \\
4500 \text { м}^{3} / \text { сут. и части } \\
\text { из общего объема }\end{array}$ \\
\hline$>10000$ & $\leq 100000$ & & $\begin{array}{c}3+1 \text { для каждых } \\
10000 \text { м³/сут. и части } \\
\text { из общего объема }\end{array}$ \\
\hline$>100000$ & & & $\begin{array}{c}12+1 \text { для каждых } \\
25000 \text { м³/сут. и части } \\
\text { общего объема }\end{array}$ \\
\hline
\end{tabular}

Примечания:

1. Зона снабжения - географически обозначенная зона, в которую питьевая вода поступает из одного или нескольких источников питьевого водоснабжения.

2. Объемы питьевой воды следует принимать средние в течение календарного года. Вместо объема питьевой воды в сутки можно использовать количество жителей в зоне снабжения с учетом того, что один человек потребляет 0,2 м³/сут. (или 200 л/сут.) питьевой воды.

3. Частота отбора проб рассчитывается следующим образом. Если объем воды составляет $4300 \mathrm{M}^{3}$ /сут., то следует отобрать 16 проб питьевой воды в год (4 - для первой 1000 м³/сут. и дополнительно еще 12 для 3300 м³/сут.). химические и экспертной оценки.

Обсуждение результатов. Мониторинг природных вод следует проводить согласно Водной Рамочной Директиве 2000/60/EC с целью изучения уязвимости водного источника к проникновению загрязнений, оценки риска загрязнения воды на сегодняшний день и в перспективе, разработки и осуществления мероприятий, направленных на постепенное устранение загрязнений природной воды. При этом следует выявлять источники их загрязнения, границы колебания концентраций загрязняющих веществ, их фоновые концентрации и т.д. Другими словами, нужно применять оценку

Показатели группы A:

a) кишечная палочка (E. coli), колиформные бактерии, ОМЧ при $t 22^{\circ} \mathrm{C}$, цветность, мутность, вкус и привкус, запах, водородный показатель, электрическая проводимость; б) другие показатели - в случае, если они могут нести потенциальную угрозу для здоровья потребителей питьевой воды и, в соответствующих случаях, на основании "оценки риска";

в) аммоний и нитрит - в случае использования хлорирования с аммонизацией; алюминий и железо - при использовании соответствующих реагентов для обработки питьевой воды.

Показатели группы Б: все остальные показатели, указанные в нормативном документе, которые не относятся к группе A. риска загрязнения воды (рекомендована ВОЗ), которая включает в себя постоянный анализ опасных факторов и событий. Для любого опасного фактора с высоким риском должны устанавливаться меры, уменьшающие риск. При выявлении рисков и событий нужно взаимодействовать со многими организациями, деятельность которых влияет на их устранение или минимизацию.

Конечной целью мониторинга водных ресурсов является окончательное устранение (или минимизация) опасных веществ в поверхностных и подземных водах. Когда водный объект испытал значительное техногенное воздействие и по какой-либо причине невозможно достичь соответствующей цели, необходимо проводить мероприятия для предотвращения дальнейшего ухудшения качества вод и стремиться к поддержанию и восстановлению в них, насколько это возможно, хотя бы важнейших функций и природных свойств водных экосистем - состояния так называемого базового экологического качества [6].

$\mathrm{Ha}$ сегодняшний день в Украине отменено действие СанПин 4630-88 "Санитарные правила охраны поверхностных вод от загрязнения", в которых регламентированы требования к воде источников питьевого водоснабжения. Взамен введен в действие ДСТУ 4808:2007 "Источники централизованного питьевого водоснабжения. Гигиенические и экологические требования к качеству воды и правила выбора", который был гармонизирован с европейской соответствующей Директивой, однако утратившей силу в 2013 году. В действующей Директиве 98/83/ЕС отмечено, что поверхностные и подземные воды должны быть защищены от загрязнений с целью производства качественной питьевой воды либо эта же цель может быть достигнута с помощью использования соответствующего водоочистного оборудования перед ее поступлением потребителю.

Таким образом, качество воды источников питьевого водоснабжения должно обеспечивать соответствие получаемой питьевой воды норма- 


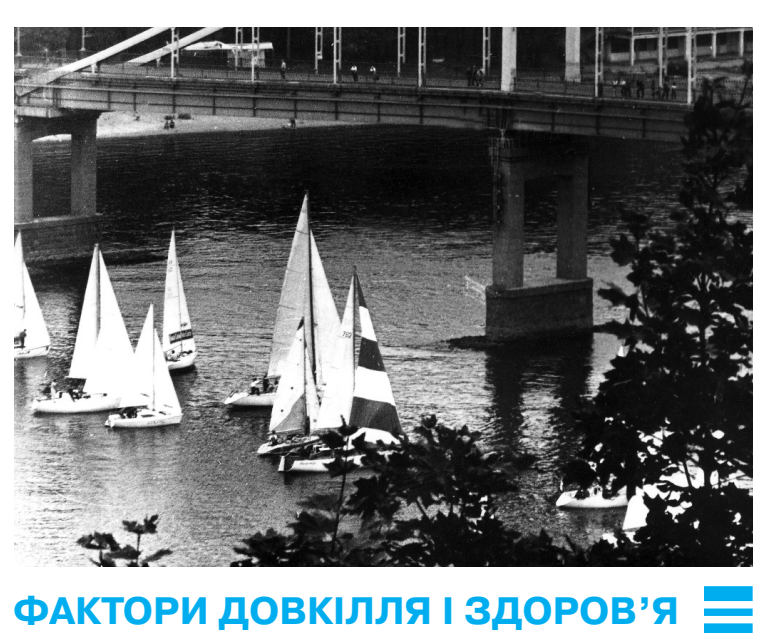

тивным требованиям с использованием необходимых современных технологий водоподготовки или без них. Перед использованием поверхностных вод предварительно проводимый мониторинг должен отражать их качество как минимум в течение трех лет, подземных - в течение надлежащего времени для того, чтобы определить границы колебаний показателей качества воды. В годовом цикле необходимо выявить закономерные изменения показателей (помимо паводкового), когда качество имеет характерные особенности [7]. Перечень показателей качества должен определяться с учетом местных природных условий, санитарного состояния источника питьевого водоснабжения и прилегающей территории, а также особенностей дальнейшей обработки питьевой воды.

На основании результатов мониторинга источников питьевого водоснабжения должен разрабатываться порядок мониторинга питьевых вод. Директива 98/83/ЕС (с изменениями 2015 года) содержит минимальные требования к проведению мониторинга (табл.), по результатам которого страны ЕС каждые три года публикуют отчет о качестве питьевых вод и мерах, которые планируются или были предприняты для выполнения требований этой Директивы, с целью информирования потребителей и других стран ЕС.

Сравнительный анализ частоты проведения исследований качества водопроводной питьевой воды по микробиологическим и органолептическим показателям в распределительной сети в Директиве 98/83/ЕС и ДСанПіН 2.2.4-17110 приведен на рисунке 1

Из рисунка видно, что согласно обоим документам частота проведения исследований качества водопроводной питьевой воды по указанным показателям в распределительной сети возрастает с повышением производительности водопровода. В Европе наблюдается более интенсивный и прямо пропорциональный рост количества проб в год, в Украине - ступенчатое ограниченное повышение (от 1 до 100 проб/год). При производительности водопровода биологических и органолептических показателей, чем для водопроводов с питьевой поверхностной водой. В остальных случаях требования совпадают.

В Директиве 98/83/ЕС отсутствует периодичность контроля качества питьевой воды непосредственно после очистки (или перед подачей в распределительную сеть), которая регламентируется в ДСанПіН 2.2.4-171-10. Если сравнивать два документа относительно общего количества проб в год для контроля микробиологических и органолептических показателей, то можно увидеть следующее. Максимальная разница между указанными требованиями выявлена для питьевых водопроводов с подземной водой производительностью 11000 м³/сут. (315 проб/год) и питьевой поверхностной 12000 м $^{3}$ /сут. (358 проб/год). При продуктивности водопроводов $130000 \mathrm{M}^{3} /$ сут. с питьевой водой из поверхностных и подземных источников питьевого проб в год для контроля микро-

Рисунок 1

Периодичность отбора проб в распределительной сети для проведения исследований по микробиологическим и органолептическим показателям в Директиве 98/83/ЕС и ДСанПіН 2.2.4-171-10

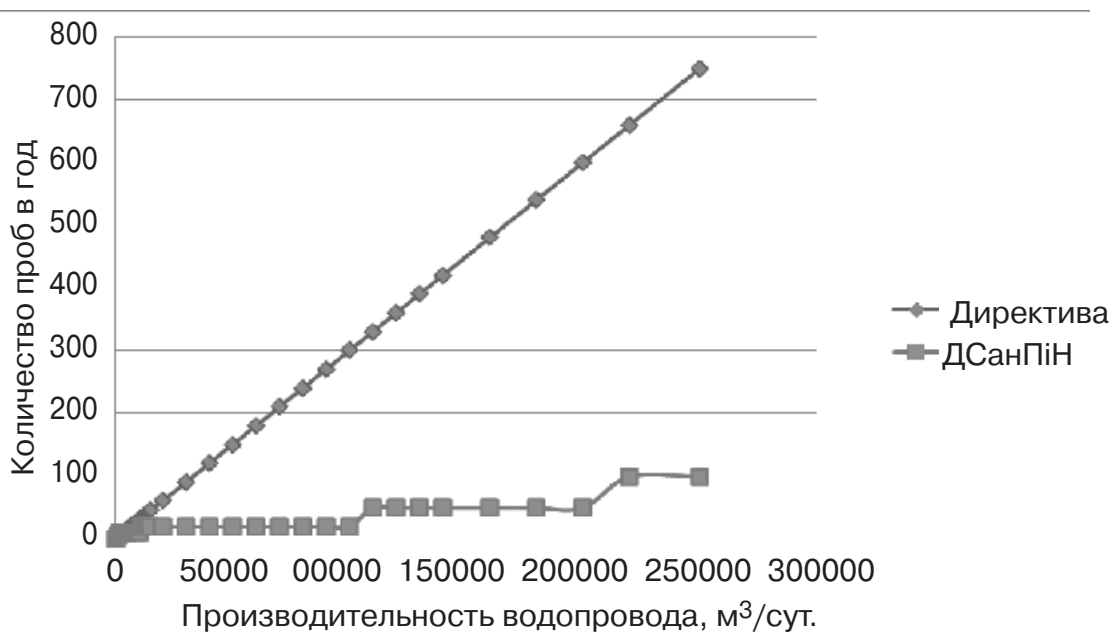


водоснабжения определяется несущественная разница (до 24 проб/год) между общим количеством отбираемых проб согласно требованиям ДСанПіН 2.2.4-171-10 и Директивы 98/83/EC.

Основываясь на положениях Директивы 98/83/EC, мероприятия по имплементации не должны негативно влиять на качество питьевой воды. Поэтому для максимального снижения риска подачи нека-

\section{Общая периодичность отбора проб водопроводной питьевой воды для проведения исследований по микробиологическим и органолептическим показателям в Директиве 98/83/ЕС и ДСанПіН 2.2.4-171-10 (для подземных вод)}

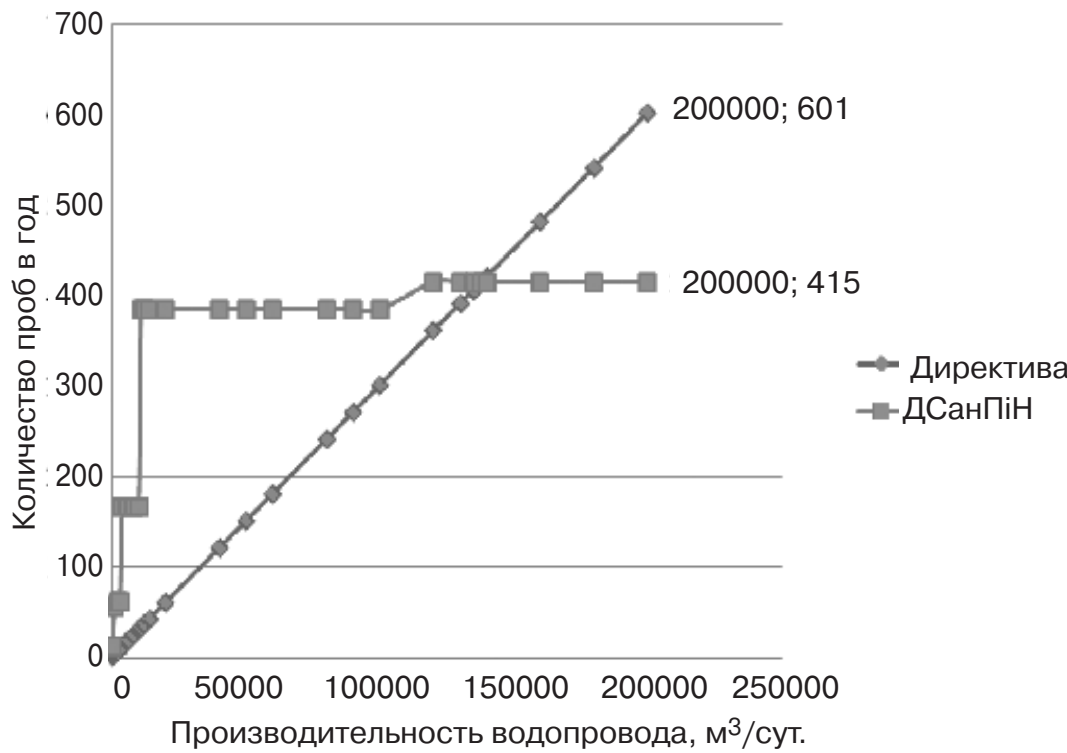

Общая периодичность отбора Ринок 3 микробиологическим и органолептическим показателям в Директиве 98/83/ЕС и ДСанПіН 2.2.4-171-10 (для поверхностных вод)

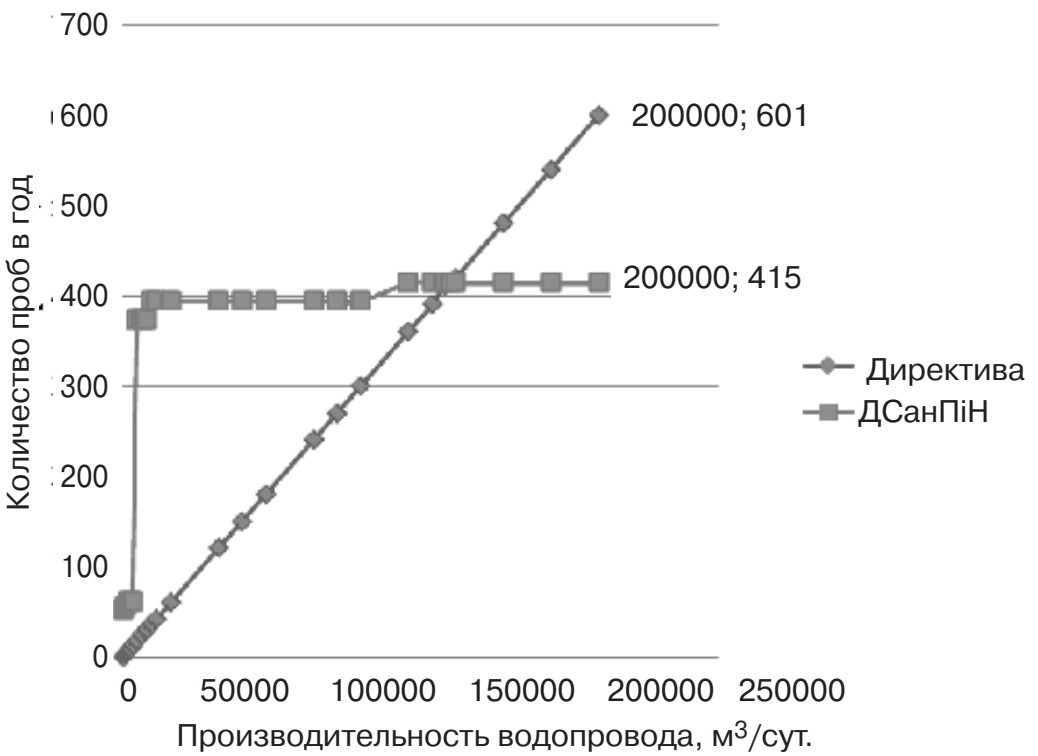

венного контроля качества питьевых вод непосредственно после ее очистки относительно содержания остаточних реагентов и гигиенических нормативов для них (отсутствуют в Директиве), а именно: остаточного свободного хлора $(0,3-0,5 \mathrm{мг/л),} \mathrm{озона}$ (0,1-0,3 мг/л), полиакриламида $(\leq 2,0 \mathrm{мг/л),} \mathrm{полифосфатов}$ $(\leq 3,5$ мг/л), кремния $(\leq 10$ $\mathrm{Mг} / л)$, диоксида хлора $(\geq 0,1$ мг/л). При использовании диоксида хлора для обеззараживания в питьевой воде образуются хлориты (норматив $\leq 0,2$ мг/л) и хлораты (норматив <20 мг/л), для которых согласно рекомендациям ВОЗ необходимо ужесточить норматив до 0,7 мг/л. Как свидетельствуют наши исследования, при ужесточении норматива для хлоратов увеличивается риск их появления в сверхнормативном количестве в питьевой воде, что требует проведения периодического их контроля не реже одного раза в месяц [8].

Проведенные нами исследования показали, что тригалогенметаны являются одними из приоритетных загрязнений в доочищенных питьевых водах из поверхностных источников (выявляются более чем в 50\% проб). Причины этого - отсутствие контроля содержания этих веществ до 2010 года, недостаточный контроль со стороны контролирующих органов и редкое их определение при производственном контроле. Нами предлагается проводить контроль качества доочищенных питьевых вод относительно содержания тригалогенметанов (суммы) не один раз в год, а один раз в три месяца, так как изменение концентраций этих веществ в водопроводной питьевой воде имеет сезонную зависимость [1].

Результаты наших исследований выявили, что на сегодняшний день более 50\% питьевых вод из пунктов разлива производят питьевые воды с низким содержанием минеральных веществ (сухим остатком меньше 100 мг/л) несмотря на то, что научно обосновано негативное влияние таких вод на здоровье потребителей [1] и их использование запрещено законодательством. Чтобы изменить создавшуюся на сегодня ситуацию при исполь- 
SCIENTIFIC SUBSTANTIATION OF IMPROVEMENT OF THE ECOLOGICAL-HYGIENIC MONITORING PROCEDURE OF POTABLE AND NATURAL WATERS QUALITY Zorina O.V.

State Institution "O.M. Marzeiev Institute for Public Health" NAMSU, Kyiv

The study is aimed at scientific substantiation and improvement of parameters and criteria of the potable and natural waters quality monitoring in accordance with the requirements of the European legislation.

Materials. The analysis was carried out of the European and Ukrainian regulatory documents regarding the potable and natural waters quality. The quality of potable tap water from surface and subsurface sources of drinking water supply, in the bottling places, and packaged was investigated for meeting sanitary-chemical indicators in different regions of Ukraine during the last 17 years (more than 600 samples).

Methods: bibliographical, regulatory-searching, hygiene, sanitary-chemical, and expert evaluating. Main results. The work consist of the scientific substantiation, systematization, and improvement of parameters and criteria of potable and natural waters quality monitoring in accordance with the requirements of the European legislation and on the basis of longitudinal research of priority indicators of the potable and natural waters quality, as well as the potable water influence on the consumer health. It is noted that the development of the program for monitoring the drinking water should be conducted taking into account the results of monitoring of natural waters. Improved analysis criteria that should be conducted in case of water monitoring development, it is proposed to analyze the presence of problem indicators, which concentration was unstable and exceeded $75 \%$ of the norm, as well as before cleaning exceeded the hygienic norm for drinking water. The comparative assessment of Directive 98/83/EC and ДСанПіН 2.2.4-171-10 concerning the procedure for monitoring the quality of drinking water by microbiological and organolep- tic indicators showed that at the productivity of the water supply system up to $130000 \mathrm{~m}^{3}$ /day in the ДСанПін the stricter control is regulated, which requires preservation in in case of implementation of the said directive. It has been found that Directive 98/83/EC does not have a procedure for monitoring the quality of drinking water in relation to the content of residual quantities of reagents and the hygiene standard for them (regulated in ДСанПін 2.2.4-171-10), which needs to be preserved in the revised national regulatory document. We have found that refined drinking water of superficial sources of drinking water supply has a stable composition. Requirements for the quality of such waters and periodicity of their quality control are determined (coincide with the requirements for underground drinking water). The periodicity of mineral substances determination in potable water with artificial mineralization in potable water was reduced in bottling places with productivity less than

$5 \mathrm{~m}^{3} /$ day in order to prevent the production and sales of the desalinated water (earlier - one time a week, now - one time per month). The standard for chlorates was established according to the WHO $(0,7 \mathrm{mg} / \mathrm{l})$ recommendations and the periodicity of the chlorates level control was set (one time per month in case of potable water disinfection with the chloride dioxide); stricter control of potable water quality was set for the content of trihalomethanes (in case of minimization of their content-at least on time per three months). It was pointed for the first time that after the water supply systems refurbishment and changes in the water treatment technology the manufacturers can carry out the potable water quality control not of a full list of the indicators, but only for those that can be changed, what is cost-effective. It was determined that there is a need in implementation of complex ecological hygienic monitoring of natural and potable waters as of today, what will be a significant step in improvement of the potable waters quality and European legislation implementation in Ukraine.

Keywords: monitoring, natural waters, potable waters, meeting criteria, periodicity of monitoring. зовании автоматических систем дозирования, нами предлагается проводить разъяснительную работу среди потребителей, а также снизить частоту контроля минеральных веществ, которые добавляются в воду, с одного раза в неделю до одного раза в месяц.

На сегодняшний день после переоборудования системы водоснабжения и изменений в технологии требуется проведение полного анализа, что может быть фактически и экономически нецелесообразным. Нами предлагается в указанных случаях проводить исследования качества воды только по показателям, которые могут изменяться из-за проведения указанных мероприятий.

Для водопроводной питьевой воды после дополнительной очистки, которая поступа- ет непосредственно в водопроводную сеть потребителя, нами впервые обоснованы показатели ее качества и периодичность контроля. По нашим данным, качество таких вод практически соответствует качеству вод из подземных источников, при котором подземная вода не требует корректировки. Требования $\mathrm{k}$ качеству таких вод не должны отличаться от требований для водопроводной питьевой воды, как и частота отбора проб для проведения их лабораторного контроля.

Как уже указывалось, контроль качества водопроводной питьевой воды в Украине в основном проводится перед ее поступлением в распределительную сеть. Согласно требованиям европейского законодательства мониторинг качества питьевой воды по всем регламентируемым показателям должен проводиться в "пунктах соответствия".

Новый термин "пункт соответствия качества питьевой воды" был введен, по нашей инициативе, в 2017 году в Закон Украины "О питьевой воде, питьевом водоснабжении и водоотведении". Пунктом соответствия считают место отбора проб воды, в котором устанавливается соответствие качества воды гигиеническим требованиям, а именно:

$\square$ из кранов систем питьевого водоснабжения - для водопроводной питьевой воды;

$\square$ в местах использования на предприятии - для питьевой воды, используемой для производственных (технологичеСКИх) нужд;

в местах разлива в тару потребителя - для питьевой 
воды из пунктов разлива питьевой воды;

в местах разлива в потребительскую тару - для фасованной питьевой воды

В пунктах соответствия должен проводиться полный анализ качества питьевой воды при вводе в эксплуатацию вновь построенных систем питьевого водоснабжения, технологических линий и распределительных сетей, их реконструкции и капитального ремонта, а также "от случая к случаю" определяются вещества и микроорганизмы, для которых не установлены требования в нормативном документе, если есть причина подозревать, что они могут присутствовать в воде в количествах, представляющих потенциальную опасность для здоровья потребителей.

Согласно Директиве 98/83/EC мониторинг питьевой воды в "пунктах соответствия" должен проводиться постоянно и отображать ее качество в течение года. Программы мониторинга должны предусматривать

$\square$ сбор и анализ качества отобранных проб воды;

$\square$ и/или измерения, которые фиксируются с помощью непрерывного процесса мониторинга.

Кроме того, программы мониторинга могут включать

$\square$ проверку отчетов о состоянии функциональности и технического обслуживания оборудования;

и/или обследование водосборной площади и водозабора, водопроводных сооружений и установок, мест хранения и распределения.

На основании вышеуказанного компетентные органы должны разрабатывать программу мониторинга питьевой воды (технологическую инструкцию), которая позволит оценить результаты мониторинга воды источника питьевого водоснабжения, особенности технологии ее обработки, условия хранения и транспортировки, производительность систем питьевого водоснабжения, наличие проблемных показателей качества питьевой воды и др. По нашему мнению, к проблемным показателям следует относить такие показатели, концентрации которых превышают гигиенический норматив для пить- евых вод до или/и после очистки, а также нестабильны и приближены к уровню указанного норматива (более 0,75 норматива).

Программы мониторинга могут быть основаны на общих принципах оценки риска, изложенных в международных стандартах, в частности стандарте EN 15975-2. Оценка риска проводится с целью определения возможности внесения изменений в порядок мониторинга качества воды в пунктах соответствия. Например, при наличии водопроводной сети пробы могут отбираться в зоне подачи воды или на очистных сооружениях для конкретных показателей качества, если возможно доказать, что содержание вещества не может ухудшаться в течение транспортировки питьевой воды в водопроводной сети. При проведении оценки риска количество показателей для проведения мониторинга качества питьевой воды или частота отбора проб может быть увеличена или уменьшена. При этом анализируются

口присхождение соответствующего вещества, а также изменчивость и долгосрочность тенденции его содержания;

в вещества, концентрации которых составляют менее $60 \%$ от норматива в случае отбора проб в течение не менее 3 лет из точек отбора проб, представляющих все зоны подачи;

в вещества, концентрации которых составляют менее 30\% от норматива в случае отбора проб в течение не менее 3 лет из точек отбора проб, представляющих все зоны подачи;

$\square$ результаты мониторинга источников питьевого водоснабжения (Директива 2000/60/EC).

Результаты оценки риска должны подтвердить, что ни один фактор, который потенциально может ожидаться, вероятно, не приведет к ухудшению качества питьевой воды, а здоровье потребителя будет защищено

Надлежащие программы мониторинга (на основании оценки рисков или без нее) должны разрабатываться компетентными органами, рассматриваться на постоянной основе, обновляться или продлеваться каждые пять лет, краткое изложение результатов оценки риска должно быть информацией, доступной для общественности.

Новые требования к порядку проведения мониторинга качества питьевых вод должны распространяться на все виды питьевых вод и быть обязательными для всех, кто занимается производством питьевой воды, то есть забором воды из источников питьевого водоснабжения и/или доведением ее качества до требований на питьевую воду. Необходимо отметить, что в 2017 году по нашей инициативе в Законе Украины "О питьевой воде, питьевом водоснабжении и водоотведении" определение термина "производство питьевой воды" было изменено. Вышеуказанный мониторинг питьевой воды должен проводиться и на предприятиях пищевой промышленности для технологической воды, кроме случаев, когда орган исполнительной власти, реализующий государственную политику в области санитарного законодательства, считает, что использование такой воды негативно не влияет на безопасность готового продукта питания.

Проведение комплексного мониторинга природных и питьевых вод позволит проводить глубокий анализ состояния вод, разрабатывать и своевременно внедрять мероприятия для защиты здоровья потребителей питьевой воды.

\section{Выводы}

1. Одной из причин несоответствующего качества питьевой воды является отсутствие комплексного мониторинга качества природных и питьевых вод. Разработка программы порядка мониторинга качества питьевых вод с учетом его результатов позволит разработать научно обоснованные мероприятия и рекомендации по предупреждению заболеваемости населения, связанного с водным фактором.

2. С учетом требований европейского законодательства научно обоснованы параметры и критерии, усовершенствован алгоритм проведения мониторинга качества питьевых вод, что позволит унифицировать подготовку материалов о качестве питьевых вод для информирования стран Европейского Союза и потребителей. 
3. Выявлено, что в Директиве 98/83/ЕС требования к частоте проведения исследований по микробиологическим и органолептическим показателям при производительности водопровода $<130000$ м³/сут менее жесткие, чем действующие ныне в Украине. Следовательно, при имплементации европейского законодательства в Украине необходимо в обновленном нормативном документе максимально приблизить периодичность контроля качества питьевой воды непосредственно после очистки по органолептическим и микробиологическим показателям к регламентируемой на сегодняшний день с целью производства питьевой воды гарантированного качества. Следует сохранить действующий порядок производственного контроля качества питьевой воды относительно содержания остаточных концентраций реагентов и гигиенические нормативы для них (что отсутствует в Директиве 98/83/EC); изменить норматив для хлоратов согласно рекомендациям ВО3 (0,7 мг/л) и регламентировать периодичность контроля этого вещества в питьевой воде; внести изменения в периодичность контроля доочищенных питьевых вод (искусственно минерализированных и после очистки от тригалогенметанов); указать требования и периодичность контроля для доочищенных питьевых вод, поступающих в водопроводную сеть; внедрить общие требования к периодичности исследований для всех видов питьевых вод.

4. Новый порядок комплексного мониторинга состояния природных и питьевых вод повысит эффективность функционирования и совершенствование технологической системы подготовки питьевой воды, что позволит подавать потребителю питьевую воду более стабильного и гарантированного качества.

ЛИТЕРАТУРА

1. Прокопов В.О. Питна вода України: медико-екологічні та санітарно-гігієнічні аспекти. К. : Медицина, 2016. 400 с.

2. Сташук В.А., Яцик А.В. До питання водної політики в Україні. Сучасні проблеми охорони довкілля, раціонального використання водних ресурсів та очистки природних і стічних вод : зб. тез доп. міжнародної наук.-практ. конф. К., 2007. C. $162-166$.

3. Гаркавий С.І., Сало Т.Л., Чорнокозинський А.В. Екологічні та санітарно-гігієнічні аспекти впливу скиду стічних вод міст на якість поверхневих вод басейну р. Дніпро. Науковий вісник Національного медичного університету імені О.О. Богомольця. 2010. № 27. С. 83-92.

4. Левицька С.П. Сучасний вплив антропогенного навантаження на якісний стан поверхневих вод України. Міжнародний Водний Форум "АКВА УКРАЇ̈А-2004": зб. тез доп. наук.-практ. конф. К. 2004. C. 56-57.

5. Луцько В.С. Екологічна безпека водних ресурсів України в умовах глобалізації. Міжнародний Водний Форум "АКВА УКРАЇНА-2003": зб. тез доп. наук.-практ. конф. К., 2003. C. 21-29.

6. Гончарук В.В., Жукинский В.Н., Чернявская А.П., Скубченко В.Ф. Разработка эколого-гигиенической классификации качества поверхностных вод Украины источников централизованного питьевого водоснабжения. Химия и технология воды. 2008. Ч. II. C. 3-51.

7. Харабрин А.В. Экологический мониторинг качества воды и оценка барьерной роли сооружений водоподготовки (на примере Северного ковшового водопровода г. Уфы) : автореф. дис. ... канд. тех. наук. Уфа., 2004. 24 с.

8. Мокиенко А.В., Петренко Н.Ф., Гоженко А.И.

Обеззараживание воды.

Гигиенические и медико-экологические аспекты. Диоксид хлора: монография. Одесса ТЭС, 2012. Т. 2. 650 с.

\section{REFERENCES}

1. Prokopov V.O. Pytna voda Ukrainy: medyko-ekolohichni ta sanitarno-hihienichni aspekty [Drinking Water of Ukraine: Medico-Ecological and Sanitaryand-Hygienic Aspects]. Kyiv : Medytsyna; 2016 : 400 p. (in Ukrainian)

2. Stashuk V.A. and Yatsyk A.V. Do pytannia vodnoi polityky v Ukraini [To the Issue of Water Policy in Ukraine]. In : Suchasni problem okhorony dovkillia, ratsionalnoho vykorystannia vodnykh resursiv ta ochystky pry- rodnykh I stichnykh vod : mater. konf. [Modern Problems of the Environment Protection and Rational Use of Water

Resources and Treatment of Natural and Waste Water : Mater.]. Kyiv ; 2007 : 162-166 (in Ukrainian).

3. Harkavyi S.I., Salo T.L. and Chornokozynskyi A.V. Naukovyi visnyk Natsionalnoho medychnoho universytetu im. O.O. Bohomoltsia. $2010 ; 27: 83-92$

(in Ukrainian)

4. Levytska S.P. Suchasnyi vplyv antropohennoho navantazhennia na yakisnyi stan poverkhnevykh vod Ukrainy [Modern Impact ofthe Anthropogenic Load and Quality State of the Surface Water of Ukraine]. In : Mizhnarodnyi vodnyi forum "AKVA UKRAINE2004": materialy [AQUA UKRAINE-2004. International Water Forum : Mater.]. Kyiv; 2004 : 56-57 (in Ukrainian).

5. LutskoV.S. Ekolohichna bezpeka vodnykh resursiv Ukrainy v umovakh hlobalizatsii [Ecological Safety of Water Resources of Ukraine under Conditions of Globalization]. In : Mizhnarodnyi vodnyi forum "AKVA UKRAINE-2003" : materialy. [AQUA UKRAINE-2003. International Water Forum Mater.]. Kyiv; 2003 : 21-29 (in

Ukrainian).

6. Honcharuk V.V., Zhukinskiy V.N., Cherniavskaya A.P. and Skubchenko V.F. Khimiia $i$ tekhnologiia vody. 2008 ; P. II : 3-51 (in Russian).

7. Kharabrin A.V. Ekologicheskiy monitoring kachestva vody I otsenka bariernoi rol sooruzheniy vodopodgotovki (na primere Severnogo kovshovogo vodoprovoda g. Ufy [Ecological Monitoring of Water Quality and Assessment of Barrier Role of Water Treatment Facilities (at the Example of the North Bucket Water Pipe-Line of the City of Ufa) : Author's Abstract of the Dissertation to the Degree of the Candidate of Technical Sciences]. Ufa, Russia ; 2004 : 24 p. (in Russian)

8. Mokienko A.V., Petrenko N.F. and Gozhenko A.I. Obezzarazhivanie vody. Gigienicheskie i mediko-ekologicheskie aspekty [Water Disinfection. Hygienic and Medico-Ecological Aspects. Chlorine Dioxide]. Odessa : TES; 2012 ; 2 : 650 p. (in Russian). Надійшло до редакції 04.02.2018 